208 放射性医薬品手動注入器 (AZ-1602)について 安西メディカル(株) ·本社営業部 長田一郎

【目的】近年, FDGの認可によりPETが普及し始めました．PET薬剤 は短半減期で高いエネルギーを放出するため, 特に被曝に関して

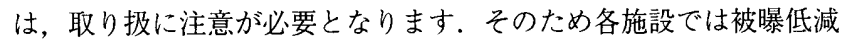
のためにいろいろな工夫をしておりますが，この度弊社は患者様へ の薬剤投与の際に少しでも被曝低減するために放射性医薬品手動注 入器 (AZ-1601)を開発いたしました. 現在, 薬剤投与は医師または 看護師の仕事になっています。これらの方々の誰もが簡単に扱え, 被曝低減を可能にした注入器です。

【特長】1.RI医薬品投与時における医師または看護師の外部被曝を低 減できます，2，安全に注入過程を目視確認することができるため に，鉛ガラスを投与部分とRIシリンジ部分に配置しました．３．市 販のディスポ製品を使用するので特別な操作方法を習得する必要も なく, RIシリンジのプランジャーを押す動作では，抵抗がないので 今までどおりの注入操作で簡単に扱うことができます。 4. 本体は大 型のキャスターが付いているため, 移動が容易に行えます，処置室 や検査室などの使用場所を限定しません．5. 患者様の薬片注入姿勢 を楽にするため(身長差に対応できるように)上肢台の部分は, 上下 可動します。なお，PET装置の寝台から投与する場合でも使用でき ます. 6. 対応するRI医薬品のシリンジサイズは $20 \mathrm{ml}$ まで可能とし ました。

【結論】 ${ }^{18}$ F-FDGを医師または看護師が投与する際，AZ-1601を使用す ることにより，AZ-1601を使用しなかった場合に比べ，約 $84 \%$ の被 曝を低減させることができました。このことから薬剤投与時に対す る医師または看護師の被曝低減に非常に有用性があります。

209 プレゼンテーションLUT対応インクジェットプリンタの開発 キヤノン(株) 佐田浩一，齋藤秀彦，小倉 隆，松本和正，鈴木健一 【目的】国内でも電子カルテ化が進み，フィルムレス・モニ夕診断が 盛んになりつつあるが, キ一画像だけはハードコピーしておきたい という要望は依然残っている。しかし，モニタ上でキー画像をプリ ントしても，モニタ表示された画像とハードコピーした画像は異 なって見え，それを一致させるには煩雑な調整操作が必要であっ た. DICOMでは，モニタやハードコピーといった異なる装置の画像 の見え方を一致させるGrayscale Standard Display Function (GSDF)を 規定している。このGSDFを我々の開発したインクジェットプリン タCXJ-3000にも適用した．今回，このプリンタを用いて光沢紙に出 力したものが，モニタ表示およびフィルム出力したものと実際に類 似して見えるかどうか検証を行った。

【方法】16ステップのグレースケール画像を, 以下の 3 通りの方法で 出力し, 観察した. (1) 画像処理をせずにレーザーイメージャでフィ ルムに出力し, シャーカステンにかけて観察, (2) 画像をP-Valueに 変換したのちCXJ-3000のGSDF(プレゼンテーションLUT)対応モー ドで光沢紙に出力し, 出力した光沢紙を蛍光灯下で観察, (3) 画像を P-Valueに変換し, GSDF対応のモニタで観察.

【結果】3 通りの方法は視覚的に同一であることを確認した。今回の 結果により，従来フィルム出力しかハードコピーする手段がなかっ たキー画像も, 紙に出力しても同様なコントラストで観察できると いえる. 従来はフィルムに出力していたものを安価な紙に出力でき る他, 紙出力した画像は, 患者へのインフォームドコンセント, 他 施設への紹介用など，患者のサービス向上に大きく貢献すると思わ れる。

210 超音波診断装置 $\mathrm{Aplio}{ }^{\mathrm{TM}}$ Innovation2004の開発 東芝メディカルシステムズ(株) ·超音波事業部超音波開発部 潟口宗基

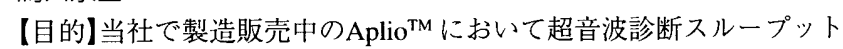

向上のためにInnovation2004の開発を行った．商品コンセプトは， (1) 超音波ルーティン検査の効率向上, (2) 超音波診断機器による治 療支援機能の強化, (3) 超音波診断装置の特徴となる次世代映像技術 の実現である.

【方法】QuickScanは, 従来, 検查者が行っていた断層像の輝度や画質 調整を 1 ボタンで自動的に最適設定にする機能. iAssist ${ }^{\mathrm{TM}}$ では, 事 前に登録された操作手順を 1 ボタンで自動的に設定し, 検査者の負 担を軽減できる，腹部の特に肋間からの穿刺術のガイドに特化した 新プローブPVT-382BTは超音波造影の性能も極めて高くRFによる治 療等へ応用される. MicroFlowImagingは, 超音波造影剂と組み合わ せることにより肝臓等の微小血管まで描出可能にした技術．新ブ ロードバンドテクノロジーとDifferential-THIと組み合わせることに より, 従来THIでは得られなかった高感度・高分解能なB断層画像を 実現した。これらの技術の開発により, 超音波診断における, 操作 性や診断能を大幅に向上することができることを評価確認した．

【結諭】Aplio ${ }^{\mathrm{TM}}$ Innovation2004により実現された機能により, 治療支 援の展開, 超音波ルーティン検查効率向上, 次世代映像技術の開発 を達成した。

\section{1 超音波診断装置EUB-8500/6500の新技術}

(株)日立メディコ・US事業戦略室 岡田一孝

(株)日立メディコ・技術研究所 荒井 修、三竹 毅

(株)日立メディコ・USシステム本部 安喰直子

【目的】現在, 肝臓腫瘍の診断においては, 蔵器の位置関係の把握が 容易なCT装置が多用されています。一方, 肝蔵腫瘍の治療において は, RFA治療 (Radio Frequency Ablation：ラジオ波焼灼療法)が盛ん に行われる様になりました. RFAは, 穿刺針の先端からのラジオ波 で病巣を熱凝固壊死させる治療法であり, 1 回の治療範囲が広い, 短時間で癌細胞を熱凝固壊死させられるという特長を持ち, 治療成 績が良好です．開腹手術に比へ，患者への負担が軽くてすみます． このRFA治療の際には, 穿刺のガイドとして, 放射線被曝がなく, リアルタイムで観察できる超音波装置が多く使用されています。と ころが, 超音波装置では, 肺や胁骨が障害となり, 目的の腫瘍を捉 えるのが困難な場合があり, 腫瘍の位置を把握するため, 予め撮影 しておいた静止画のCT画像を参照することが多く行われています. ところが, 超音波装置は, 手動で任意の断面を画像化するのに対 し，CT装置は体軸に対して直行する輪切りの断面を画像化するの で, 断面方向が異なり, 直接的な画像比較が困難です。これらの課 題を解決するため, 超音波と同一断面のCT像をリアルタイムに表示 するシステムを検討しました。

【方法】超音波探触子に磁気センサを取り付け, 磁気により探触子の 位置と角度を検出し，この位置情報から，予め取得しておいたCTの ボリュームデータをワークステーションで高速演算するシステムと しました。

【結果】このシステムにより，超音波と同一断面のCT像をリアルタイ ムに表示することができました。診断や, RFA治療のみならず，超 音波装置の操作に関する教育への貢献が期待できます。このシステ ムは, Real-time Virtual Sonographyとし, EUB-8500/6500への接続 を実現しました。

\section{2 新しい造影㘊注入方法の開発}

\section{(株) 根本杏林堂·企画課 傳法昌幸}

長野赤十字病院·中央放射線部 八町 淳

【目的】近年マルチスライスCTの普及により, 造影検査も多様化しさ まざまな検査に適応されるようになってきた。 それにともないCT装 置の性能, 特徴を充分に引き出すための造影剂の注入方法も検討さ れている。しかし今までの設定方法ではある程度限界があり, 検査 目的にあった造影条件のより簡便な設定が求められている。そこで 